\title{
Deposition of yttria-stabilized zirconia thin films by high power impulse magnetron sputtering and pulsed magnetron sputtering
}

Steffen Sønderby, Asim Aijaz, Ulf Helmersson, Kostas Sarakinos and Per Eklund

\section{Linköping University Post Print}

\section{Tweet}

N.B.: When citing this work, cite the original article.

Original Publication:

Steffen Sønderby, Asim Aijaz, Ulf Helmersson, Kostas Sarakinos and Per Eklund, Deposition of yttria-stabilized zirconia thin films by high power impulse magnetron sputtering and pulsed magnetron sputtering, 2014, Surface \& Coatings Technology, (240), 1-6.

http://dx.doi.org/10.1016/j.surfcoat.2013.12.001

Copyright: Elsevier http://www.elsevier.com/

Postprint available at: Linköping University Electronic Press http://urn.kb.se/resolve?urn=urn:nbn:se:liu:diva-102516 


\section{Accepted Manuscript}

Deposition of yttria-stabilized zirconia thin films by high power impulse magnetron sputtering and pulsed magnetron sputtering

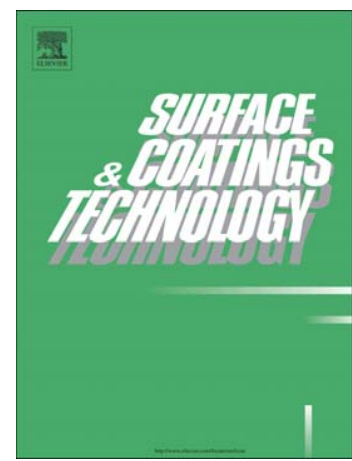

Steffen Sønderby, Asim Aijaz, Ulf Helmersson, Kostas Sarakinos, Per Eklund

PII:

S0257-8972(13)01145-6

DOI:

doi: 10.1016/j.surfcoat.2013.12.001

Reference:

SCT 19046

To appear in: $\quad$ Surface \& Coatings Technology

Received date: 23 September 2013

Accepted date: 4 December 2013

Please cite this article as: Steffen Sønderby, Asim Aijaz, Ulf Helmersson, Kostas Sarakinos, Per Eklund, Deposition of yttria-stabilized zirconia thin films by high power impulse magnetron sputtering and pulsed magnetron sputtering, Surface \& Coatings Technology (2013), doi: 10.1016/j.surfcoat.2013.12.001

This is a PDF file of an unedited manuscript that has been accepted for publication. As a service to our customers we are providing this early version of the manuscript. The manuscript will undergo copyediting, typesetting, and review of the resulting proof before it is published in its final form. Please note that during the production process errors may be discovered which could affect the content, and all legal disclaimers that apply to the journal pertain. 
Deposition of yttria-stabilized zirconia thin films by high power impulse magnetron sputtering and pulsed magnetron sputtering

Steffen Sønderby ${ }^{\mathrm{a}, \mathrm{b}, *}$, Asim Aijaz $^{\mathrm{a}}$, Ulf Helmersson ${ }^{\mathrm{a}}$, Kostas Sarakinos ${ }^{\mathrm{a}}$, Per Eklund ${ }^{\mathrm{a}}$

${ }^{a}$ Department of Physics, Chemistry and Biology, IFM, Linköping University, SE-581 83 Linköping, Sweden

${ }^{b}$ Danish Technological Institute, Tribology Centre, Teknologiparken, Kongsvang Allé 29, DK8000 Aarhus C, Denmark

*Corresponding author. Tel: +45-7220 2795; Fax: +45-7220 1550; E-mail: stso@dti.dk

\section{Keywords:}

HiPIMS, HPPMS, pulsed DCMS, SOFC, YSZ, Substrate bias 


\begin{abstract}
Yttria-stabilized zirconia (YSZ) thin films were reactively sputter-deposited by high power impulse magnetron sputtering (HiPIMS) and pulsed direct current magnetron sputtering (DCMS). The use of substrate bias voltage was studied in both modes of deposition as a process parameter to promote the growth of dense and less columnar films. Films were deposited on both $\operatorname{Si}(100)$ and NiO-YSZ fuel cell anodes. The texture, morphology and composition of the deposited films were investigated with regard to their application as thin electrolytes for solid oxide fuel cells (SOFCs). Independent of the deposition mode the films were found to be stoichiometric. The application of substrate bias voltage had opposite effects on texture and crystallinity of films deposited by pulsed DCMS and HiPIMS. Films deposited by pulsed DCMS became highly crystalline and $\langle 220\rangle$ textured at high bias voltage whereas bias applied to HiPIMS deposited films disrupted crystal growth leading to deterioration of crystallinity. Comparing film morphology, it was found that pulsed DCMS films were columnar and contained voids regardless of the applied substrate bias. When depositing by HiPIMS a window of operation at a bias voltage of $-25 \mathrm{~V}$ to $-50 \mathrm{~V}$ was found in which it is possible to deposit non-columnar thin films without voids and cracks as desired for SOFC applications.
\end{abstract}




\section{Introduction}

Yttria-stabilized zirconia (YSZ) is the most commonly used material for solid oxide fuel cell (SOFC) electrolytes [1] as it is an adequate ionic conductor, has a low electronic conductivity, and is relatively cheap to process compared to other electrolyte materials. The ionic conductivity in the stabilized zirconia system is due to the mobility of $\mathrm{O}^{2-}$ vacancies created when substituting $\mathrm{Zr}^{4+}$ by $\mathrm{Y}^{3+}$ in the cationic network. However, the ionic conductivity of state-of-the-art YSZ based electrolytes is only sufficient at elevated temperatures $\left(800-1000{ }^{\circ} \mathrm{C}\right)$ which results in increased reactivity of cell core components, drastically limited lifetimes and requires the use of expensive interconnect materials[2]. Therefore, the reduction of the operation temperature to an intermediate temperature range $\left(500-750^{\circ} \mathrm{C}\right)$ is a key objective in SOFC research. Among the possible routes to achieving lower operation temperatures, reduction of the electrolyte thickness in order to reduce the overall resistance is promising $[3,4]$.

YSZ electrolytes are typically fabricated by screen printing or spraying techniques followed by subsequent sintering [5] which are ideal for low-cost fabrication with high throughput. However, these methods are not suitable for producing dense and thin (a few $\mu \mathrm{m}$ in thickness) YSZ electrolytes. The latter can be achieved by synthesizing YSZ thin films employing a variety of chemical and physical methods [6] such as pulsed laser ablation (PLD) [7,8] chemical vapor deposition (CVD) [9], atomic layer deposition (ALD) [10], spin coating [11] and magnetron sputtering [12,13,14,15,16,17]. An issue often encountered when depositing YSZ thin films by physical vapor deposition techniques (PVD) (e.g., magnetron sputtering) at relatively low synthesis temperatures is the formation of underdense and columnar microstructures. Such microstructures are unfavorable as they may result in internal leakage in the cell leading to decreased open cell potential. Therefore, an undesirable extra manufacturing step in the form of post-deposition annealing is often required to eliminate pores in such films [6]. Reports on cell 
tests performed on SOFCs containing magnetron sputtered electrolytes with a columnar structure have shown an electrochemical performance comparable to or worse than cells containing tape cast electrolytes and not a significant improvement as would be expected from the reduced electrolyte thickness $[18,19]$. This lack of performance is related to leaks in the electrolyte due to the columnar morphology. In contrast, Nédélec et al. have deposited electrolytes without visible continuous columnar structure and has achieved significant improved electrochemical performance at low temperatures [20].

High power impulse magnetron sputtering (HiPIMS) is a PVD-based technique for thin film deposition. Inherent to this technique is a relatively large fraction of ionization of the sputtered material with energies up to several $10 \mathrm{~s}$ of $\mathrm{eV}$ that have been shown to provide added means for controlling the microstructural evolution during film growth [21]. The latter has been, for instance, shown to favor the growth of dense films at relatively low growth temperatures and to suppress columnar microstructure giving rise to globular film morphology [22]. This is what is desired in the fabrication of thin film electrolytes for SOFC. Therefore, the goal of the present study is to explore the potential of HiPIMS for the synthesis of dense YSZ films and to establish the effect of the HiPIMS on the film morphology. Films are also synthesized by pulsed direct current magnetron sputtering (DCMS), for reference. As previous studies have shown that the substrate bias is a crucial parameter in order to obtain dense films suitable for SOFC application [20], the bias voltage has been varied between depositions. Coatings are deposited on both Si and NiO-YSZ anodes for SOFC applications and the morphological and structural features of the films are investigated.

\section{Experimental details}


Experiments were performed using a $50 \mathrm{~mm}$ diameter, $3 \mathrm{~mm}$ thick $\mathrm{Zr} / \mathrm{Y}(82: 18 \mathrm{wt} \%)$ target (purity 99.9\%, excluding Hf) equipped in a circular magnetron source placed in a cylindrical stainless steel vacuum chamber. Prior to depositions, the chamber was evacuated by a turbo molecular pump to a background pressure in the order $10^{-4} \mathrm{~Pa}$. $\mathrm{Ar}$ gas (purity 99.9997\%) was used as the sputtering gas while $\mathrm{O}_{2}$ gas (purity 99.9995\%) was used as the reactive gas. Ar and $\mathrm{O}_{2}$ gas flows were controlled by electronic mass flow controllers while the total process pressure was controlled by a gate valve. A constant Ar partial pressure of $660 \mathrm{mPa}$ was used while the $\mathrm{O}_{2}$ partial pressure was $\sim 40 \mathrm{mPa}$. Before depositions, characterization of the reactive process was performed by measuring the variations of the target voltage as a function of $\mathrm{O}_{2}$ partial pressure. The change in discharge voltage was highly dependent on the target race track depth. Even though pulsed DCMS and HiPIMS depositions were carried out at the same average power an $\mathrm{O}_{2}$ flow of $\sim 6 \mathrm{sccm}$ was needed to poison the target in the case of pulsed DCMS while only $\sim 3 \mathrm{sccm}$ was needed in HiPIMS. Films were deposited at working points that correspond to the transition zone between metallic and oxidic mode seeking to optimize the film growth rate. $\mathrm{Si}(100)$ wafers, cut into approximately $1 \times 1 \mathrm{~cm}^{2}$ pieces were coated by films with thicknesses smaller than $0.5 \mu \mathrm{m}$ and used for structural characterization and compositional analysis. NiO-YSZ SOFC anodes of size up to $5 \times 5 \mathrm{~cm}^{2}$ were coated with films with thicknesses $0.6-1 \mu \mathrm{m}$ and used to assess the morphological and structural features of the films. The NiO-YSZ anodes were supplied by Forschungszentrum Jülich GmbH (Germany) and were manufactured by reverse sequential tape casting of a thin anode on top of a thicker anode support and subsequently co-fired. The anode support was not optimized with respect to mechanical strength and was therefore too brittle to be used in cell testing experiments. For all depositions, the substrates were placed on a stationary substrate holder at a distance of $7 \mathrm{~cm}$ from the target surface and no intentional substrate heating was used. The depositions were made reactively by pulsed DCMS as well as HiPIMS. In both of 
the cases, an average power of $150 \mathrm{~W}$ was used. In the case of pulsed DCMS, the power to the cathode was applied by a pulsed DC plasma generator (ENI RPG-50) operating at a frequency of $150 \mathrm{kHz}$ with $40 \%$ duty cycle. In the case of HiPIMS, the power to the cathode was applied in the form of unipolar pulses having a frequency of $500 \mathrm{~Hz}$ and a width of $35 \mu$ s resulting in a duty cycle of $1.75 \%$. The power was supplied by a pulsing unit (SPIK 1000A, Melec) fed by an MDX $1 \mathrm{~K}$ direct current generator (Advanced Energy) operated in constant power mode. The timedependent discharge voltage and discharge current were monitored on a Tektronix TDS 520C oscilloscope. During the depositions, the energy of the depositing flux was tuned by applying a negative pulsed bias potential to the substrate using a pulsing unit (home-design) operating at a frequency of $200 \mathrm{kHz}$. The range of the substrate bias potential was chosen, in steps of $25 \mathrm{~V}$, from $-75 \mathrm{~V}$ to floating potential (no bias). In order to achieve comparable film thicknesses for characterization purposes, deposition times were adjusted to account for the lower deposition rates obtained as the bias voltage was increased and when HiPIMS was employed.

The crystalline phases and texture of the deposited films were determined by means of x-ray diffractometry (XRD). Measurements were performed in Bragg-Brentano $(\theta-2 \theta)$ with a Bruker D8 Discover diffractometer using $\mathrm{Cu} K \alpha$ radiation. Pole figures were acquired in the tilt-angle $(\chi)$ range $0-84^{\circ}$ and the azimuth-angle $(\varphi)$ range $0-360^{\circ}$ with steps of $3^{\circ}$ using a PANalytical Empyrean diffractometer. Scanning electron microscopy (SEM) was used to determine the film morphology as well as film thickness. SEM imaging was performed with a Nova 600 nanoSEM from FEI and a Zeiss EVO LS25. Both systems were equipped with an energy dispersion x-ray spectroscopy (EDX) module which was used to determine the film composition. The latter was also studied by means of Rutherford backscattering spectroscopy (RBS) using a $2 \mathrm{MeV}^{4} \mathrm{He}^{+}$ion beam from a Van de Graff accelerator and a scattering angle of $161^{\circ}$. The experimental RBS data were simulated with the SIMNRA software [23]. RBS was used to assess the global composition 
of the thin films. However, as the atomic mass of zirconium and yttrium are close they cannot be discriminated by RBS. EDX was therefore applied to estimate the ratio $\mathrm{Zr}$ and $\mathrm{Y}$ content. The $\mathrm{Zr} / \mathrm{Y}$ ratio was then used to calculate the atomic composition based on the RBS measurement. Due to overlapping ZrL and YL lines in the EDX spectrum a calibration first needed to be done by performing EDX measurements on the applied sputtering target with a known composition.

\section{Results and discussion}

Figure 1.a shows $\theta-2 \theta$ x-ray diffractograms of films deposited on $\operatorname{Si}(100)$ by HiPIMS at different bias voltages at otherwise identical conditions. The corresponding diffractograms for films grown by pulsed DCMS are seen in Fig. 1.c. For all the deposited films, the observed peaks correspond to cubic YSZ (ICDD JCP2 No. 30-1468). For films deposited by HiPIMS (Fig. 1.a) at floating potential, $-25 \mathrm{~V}$ and $-50 \mathrm{~V}$ the 220 peak is dominant while other peaks $(111,200$ and 311$)$ are very weak if present. This in combination with pole figures (not shown) at the 111, 200 and 220 peak positions show that the film has a $<220>$ fiber texture. However, the intensity and width of the peaks differ with the peak observed at $-25 \mathrm{~V}$ substrate bias being the most intense. At $-75 \mathrm{~V}$ all peaks are very weak and almost not observable when compared to the other scans. A close-up of this scan is shown separately in Fig. 1.b. Although weak in intensity, all peaks of cubic YSZ are present with the 311 peak being the most dominant. The broad amorphous halo seen at 25-40 ${ }^{\circ}$ is a diffractometer related artifact. For films deposited by pulsed DCMS (Fig. 1.c) both the 111 and 220 peaks are visible at bias voltages below $-75 \mathrm{~V}$ showing these films to have a mixed $<111>$ and $<220>$ texture whereas the film grown at $-75 \mathrm{~V}$ bias is seen to be strongly $<220>$ textured as the 220 peak dominates the diffractogram.

In contrast to the DC plasma, the HiPIMS plasma is characterized by a high electron density with substantial fraction of electrons having energies between 4 and $8 \mathrm{eV}$ [24]. It has been shown that 
the electron mean energies and plasma density can differ significantly when going from nonreactive to reactive HIPIMS [25]. Nonetheless, it is still likely that relatively high electron energies and densities can promote not only ionization of sputtered species but also dissociation of molecular $\mathrm{O}_{2}$ (the dissociation energy of $\mathrm{O}_{2}$ is $5.2 \mathrm{eV}$ [26]). This implies that a relatively large part of the reactive oxygen will be atomic during HiPIMS deposition. As described by Mahieu et al. [27, 28] the fastest growing direction under these conditions is [220] which will result in $<220>$ texture as seen in Fig. 1.a. The increase in intensity of the 220 peak observed at $-25 \mathrm{~V}$ bias compared to the film deposited at floating potential may be a result of increased ad-atom mobility due to the increased ion bombardment of positively charged particles, resulting in larger crystallites. Further increase in negative bias voltage is seen to decrease peak intensity and texturing which can be related to the increased energy of the bombarding ions becoming great enough to disrupt crystallite growth and cause repeated nucleation and a low degree of crystallinity [29]. This is in qualitative agreement with previous results reported by Alami et al. [22] for CrN films grown by HiPIMS.

Looking at Fig. 1.c., a trend is seen as substrate bias is increased from $-25 \mathrm{~V}$ to $-75 \mathrm{~V}$, the degree of $\langle 220\rangle$ orientation increases as well. However, it is unlikely that increased bias would change the reactive oxygen from the molecular to the atomic state which promotes (220) texture as described by Mahieu et al. [27,28]. However, it has previously been shown that ion bombardment promotes $<111>$ or $<220>$ texture or a mixture thereof as planes in all other directions have higher etch rates and are successfully eliminated by the shadowing process during the growth of the columns [30]. It should be noted that for films deposited on NiO-YSZ substrates an overall texturing is not to be expected as YSZ films previously have been seen to grow epitaxial on the individual grains in the substrate [31]. Therefore, films grown on the two different substrates are not directly comparable. However, studies of films grown on $\mathrm{Si}$ do reveal trends in the influence 
of deposition parameters on film growth conditions and microstructure which are likely also to be true when depositing on Ni-YSZ.

The chemical composition of the HiPIMS deposited films and some pulsed DCMS deposited films have been determined by RBS and EDX. Table I shows the atomic percentage of elements detected in the deposited films and the theoretical composition of a fully stoichiometric film sputtered from the applied target. In addition to $\mathrm{O}, \mathrm{Zr}$ and $\mathrm{Y}, \mathrm{Hf}$ is present due to its similar chemical properties with $\mathrm{Zr}$ which makes it a common impurity in commercial Zr. Within the accuracy of the measurements, the composition of the HiPIMS films is comparable to the composition of pulsed DCMS films. Also, there are no noticeable differences in the chemical composition between films deposited at different bias voltage.

Figure 2 shows SEM cross-sections of films deposited by pulsed DCMS at different bias voltages on NiO-YSZ anodes. All films look similar and appear to be columnar regardless of applied substrate bias voltage. In Fig. 3, cross sectional SEM images are shown for films deposited on NiO-YSZ by HiPIMS. The film deposited at floating potential is seen to be columnar, whereas the films deposited at $-25 \mathrm{~V}$ and $-50 \mathrm{~V}$ substrate bias are featureless. Application of $-75 \mathrm{~V}$ bias results in a film with a homogeneous, fine grained microstructure. Columnar growth is often seen in sputtered films and occurs because grain boundaries form when spatially separated nuclei (grain) impinge on each other. These boundaries become immobile when the film grows thicker. Columnar growth can be interrupted when energetic bombardment disrupts crystal growth on the surface of individual grains followed by repeated nucleation. HiPIMS is characterized by a high degree of ionization of the species involved in the deposition process, which are drawn to the substrate by the applied bias. As a result the columnar structure can be suppressed (Fig. 3.b-d). It has previously been shown that a columnar structure has a negative effect on the gas-tightness of the YSZ layers [20] and thereby also on the performance of the SOFC. 
Figure 4 shows SEM images of film surfaces of the YSZ films deposited by pulsed DCMS on NiO-YSZ substrates. The surface topography of the films replicates the shape of the underlying substrate NiO and YSZ grains. At floating potential (Fig 4.a) the continuity of the film is poor and cracks and voids are visible at the boundaries formed due to the morphology of the underlying substrate. By applying a substrate bias in the range $-25 \mathrm{~V}$ to $-75 \mathrm{~V}$ the concentration of voids is decreased (Fig. 4.b-4.d) but cannot be completely removed. Figure 5 shows the surfaces of films deposited by HiPIMS on NiO-YSZ substrates at different bias voltages. In the film grown at floating potential (Fig. 5.a) voids appear to be present as is the case when depositing by pulsed DCMS (Fig. 4). By applying a substrate bias films without voids are achieved (Fig. 5.b and c). The thin film deposited at $-75 \mathrm{~V}$ bias (Fig. 5.d) shows the fine grained, homogeneous microstructure also observed in the cross-section SEM micrograph (Fig 3.d). Adhesion problems are also observed in this sample as the film delaminates in some areas as shown in the inset. The observed fine grained, homogenous microstructure and poor adhesion may be due to the energetic ion bombardment which both strongly disturbs the nucleation and growth process and induces high stresses. Similar microstructure of YSZ has previously been reported in films prepared by pulsed DCMS at high substrate bias voltage [20]. Comparing crosssectional and surface SEM micrographs of the films deposited by HiPIMS (Fig. 3 and 5) there is a window of operation at a bias voltage between $-25 \mathrm{~V}$ and $-50 \mathrm{~V}$ in which it is possible to deposit non-columnar thin films without voids and cracks that may be suitable for SOFC application. In contrast Fig. 2 and 4 show all films deposited by pulsed DCMS to be columnar and contain voids.

\section{Conclusions}


Cubic Yttria-stabilized zirconia (YSZ) thin films were deposited by reactive magnetron sputtering in both HiPIMS and pulsed DCMS mode. The thin films were deposited on $\mathrm{Si}(100)$ as well as NiO-YSZ fuel cell anodes. In both modes of deposition the influence of substrate bias voltage on film texture, morphology and composition of the deposited films were investigated. Independent of the deposition mode the deposited films were found to be stoichiometric. When depositing by pulsed DCMS on $\mathrm{Si}(100)$ the application of $-75 \mathrm{~V}$ substrate bias results in strongly $<220\rangle$ textured films whereas bias voltages of $-50 \mathrm{~V}$ or lower result in mixed $\langle 111\rangle$ and $\langle 220\rangle$ orientation. In contrast, HiPIMS deposited films are highly crystalline and $\langle 220\rangle$ orientated when grown at a bias voltage of $-25 \mathrm{~V}$, whereas the intense ion bombardment and momentum transfer at high bias disrupt crystal growth and results in reduced grain sizes and less ordered films. Comparing film morphology of YSZ grown on NiO-YSZ anodes, it was found that pulsed DCMS films were columnar and contained voids regardless of the applied substrate bias. HiPIMS deposited films prepared at floating potential were also columnar and contained voids. By applying -75 V bias during the HiPIMS deposition a homogeneous, fine grained microstructure and minor delamination of the film was observed. At an intermediate bias voltage of $-25 \mathrm{~V}$ to -50 $\mathrm{V}$ a window of operation was found in which it was possible to deposit non-columnar thin films without voids and cracks that may be suitable for SOFC application.

\section{Acknowledgments}

The Authors would like to thank Dr. Norbert Menzler from Forschungszentrum Jülich GmbH for supplying NiO-YSZ SOFC anodes and Dr. Per Hjalmarsson from DTU Energy Conversion for technical support. Financial support from Nordforsk ref. no. 9046 (ThinSOFT), Nordic Innovation Centre ref. no. 09046 (Thin-SOFC) and the Swedish Foundation for Strategic Research is acknowledged. K.S. should like to acknowledge financial support from Linköping 
University through the "LiU Research Fellows" program and A.A. and U.H. the financial support from the Swedish Research Council, grant VR 621-2011-4280.

\section{References}

[1] B. C. H. Steele, A. Heinzel, Nature 414 (2001) 345-352.

[2] S. J. Litzelman, J. L. Hertz, W. Jung, H. L. Tuller, Fuel Cells 8 (2008) 294-302.

[3] H. Huang, M. Nakamura, P. Su, R. Fasching, Y. Saito, F. B. Prinz, J. Electrochem. Soc. 154 (2007) B20-B24.

[4] D. Beckel, A. Bieberle-Hütter, A. Harvey, A. Infortuna, U.P. Muecke, M. Prestat, J.L.M. Rupp, L.J. Gauckler, J. Power Sources 173 (2007) 325-345.

[5] N. H. Menzler, F. Tietz, S. Uhlenbruck, H. P. Buchkremer, D. Stöver, J. Mater Sci. 45 (2010) 3109-3135.

[6] L. R. Pederson, P. Singh, X.-D. Zhou, Vacuum 80 (2006) 1066-1083.

[7] J. H. Joo, G. M. Choi, Solid State Ionics 177 (2006) 1053-1057.

[8] H. Hidalgo, E. Reguzina, E. Millon, A.-L. Thomann, J. Mathias, C. Boulmer-Leborgne, T. Sauvage, P. Brault, Surf. Coat. Technol. 205 (2011) 4495-4499.

[9] G. Garcia, J. Caro, J. Santiso, J.A. Pardo, A. Figueras, A. Abrutis, Chem. Vap. Deposition 9 (2003) 279-284.

[10] J. H. Shim, C.-C. Chao, H. Huang, F. B. Prinz, Chem. Mater. 19 (2007) 3850-3854.

[11] T. Van Gestel, D. Sebold, H. P. Buchkremer, D. Stöver, J. Eur. Ceram. Soc. 32 (2012) 9-26.

[12] M. Sillassen, P. Eklund, M. Sridharan, N. Pryds, N. Bonanos, J. Bøttiger, J. Appl. Phys., 105 (2009) 104907.

[13] F. Smeacetto, M. Salvo, L. C. Ajitdoss, S. Perero, T. Moskalewicz, S. Boldrini, L. Doubova, M. Ferraris, Mater. Lett. 64 (2010) 2450-2453.

[14] S. Rey-Mermet, Y. Yan, C. Sandu, G. Deng, P. Muralt, Thin Solid Films, 518 (2009) 47434746.

[15] M. Sillassen, P. Eklund, N. Pryds, E. Johnson, U. Helmersson, J. Bøttiger, Adv. Funct. Mater. 20 (2010) 2071-2076.

[16] M. Sillassen, P. Eklund, N. Pryds, J. Bøttiger, Solid State Ionics 181 (2010) 864-867. 
[17] P. Briois, A. Billard, Surf. Coat. Technol. 201 (2006) 1328-1334.

[18] H. Hidalgo, A.-L. Thomann, T. Lecas, J. Vulliet, K. Wittmann-Teneze, D. Damiani, E. Millon, P. Brault, Fuel Cells 13 (2013) 279-288.

[19] P. Coddet, M.-C. Pera A. Billard, Fuel Cells 11 (2011) 158-164.

[20] R. Nédélec, S. Uhlenbruck, D. Sebold, V.A.C. Haanappel, H.-P. Buchkremer, D. Stöver, J. Power Sources 205 (2012) 157- 163.

[21] K. Sarakinos, J. Alami, S. Konstantinidis, Surf. Coat. Technol. 204 (2010) 1661-1684.

[22] J. Alami, K. Sarakinos, F. Uslu, M. Wuttig, J. Phys. D: Appl. Phys. 42 (2009) 015304.

[23] M. Mayer, SIMNRA User's Guide, Report IPP 9/113, Max-Planck-Institut für Plasmaphysik, Garching, Germany, 1997.

[24] J. T. Gudmundsson, J. Alami, U. Helmersson, Appl. Phys. Lett. 78 (2001) 3427-3429.

[25] M. Čada, Z. Hubička, P. Adámek, J. Klusoň, L. Jastrabík, Surf. Coat. Technol. 205 (2011) s317-s321.

[26] CRC Handbook of Chemistry and Physics, W. M. Heynes (Ed.), $93^{\text {rd }}$ Edition, 2012-2013, p.9-69.

[27] S. Mahieu, P. Ghekiere, G. Dewinter, S. Heirwegh, D. Depla, R. Degryse, O. Lebedev, G. Vantendeloo, J. Cryst. Growth 279 (2005) 100-109.

[28] S. Mahieu, P. Ghekiere, G. De Winter, D. Depla, R. De Gryse, O.I. Lebedev, G. Van Tendeloo, Thin Solid Films 484 (2005) 18-25.

[29] I. Petrov, P.B. Barna, L. Hultman, J.E. Greene, J. Vac. Sci. Technol., A 21 (2003) S117-128.

[30] N. Sonnenberg, A. S. Longo, M. J. Cima, B. P Chang, K. G. Ressler, P. C. McIntyre, Y. P. Liu, J. Appl. Phys. 74 (1993) 1027-1034.

[31] S. Sønderby, A.J. Nielsen, B.H. Christensen, K.P. Almtoft, J. Lu, J. Jensen, L.P. Nielsen, P. Eklund, Surf. Coat. Technol. 206 (2012) 4126-4131. 
List of figure captions:

Figure 1: XRD $\theta-2 \theta$ scans of: (a) HiPIMS deposited films, (b) close-up of film deposited by HiPIMS at $-75 \mathrm{~V}$ bias, and (c) films deposited by pulsed DCMS. Asterisk marks the $\mathrm{Si}(004)$ $\mathrm{CuK} \beta$ substrate peak.

Figure 2: Cross section SEM images of pulsed DCMS films. The films are deposited at (a) floating potential, (b) $-25 \mathrm{~V}$ bias, (c) $-50 \mathrm{~V}$ bias, (d) $-75 \mathrm{~V}$ bias.

Figure 3: Cross section SEM images of HiPIMS films. The films are deposited at (a) floating potential, (b) $-25 \mathrm{~V}$, (c) $-50 \mathrm{~V}$, (d) $-75 \mathrm{~V}$.

Figure 4: SEM images of pulsed DCMS film surfaces. The films are deposited at (a) floating potential, (b) $-25 \mathrm{~V}$ bias, (c) $-50 \mathrm{~V}$ bias, (d) $-75 \mathrm{~V}$ bias.

Figure 5: SEM images of HiPIMS film surfaces. The films are deposited at (a) floating potential, (b) $-25 \mathrm{~V}$ bias, (c) $-50 \mathrm{~V}$ bias, (d) $-75 \mathrm{~V}$ bias. Inset in (d) shows a defect where the film delaminates. 


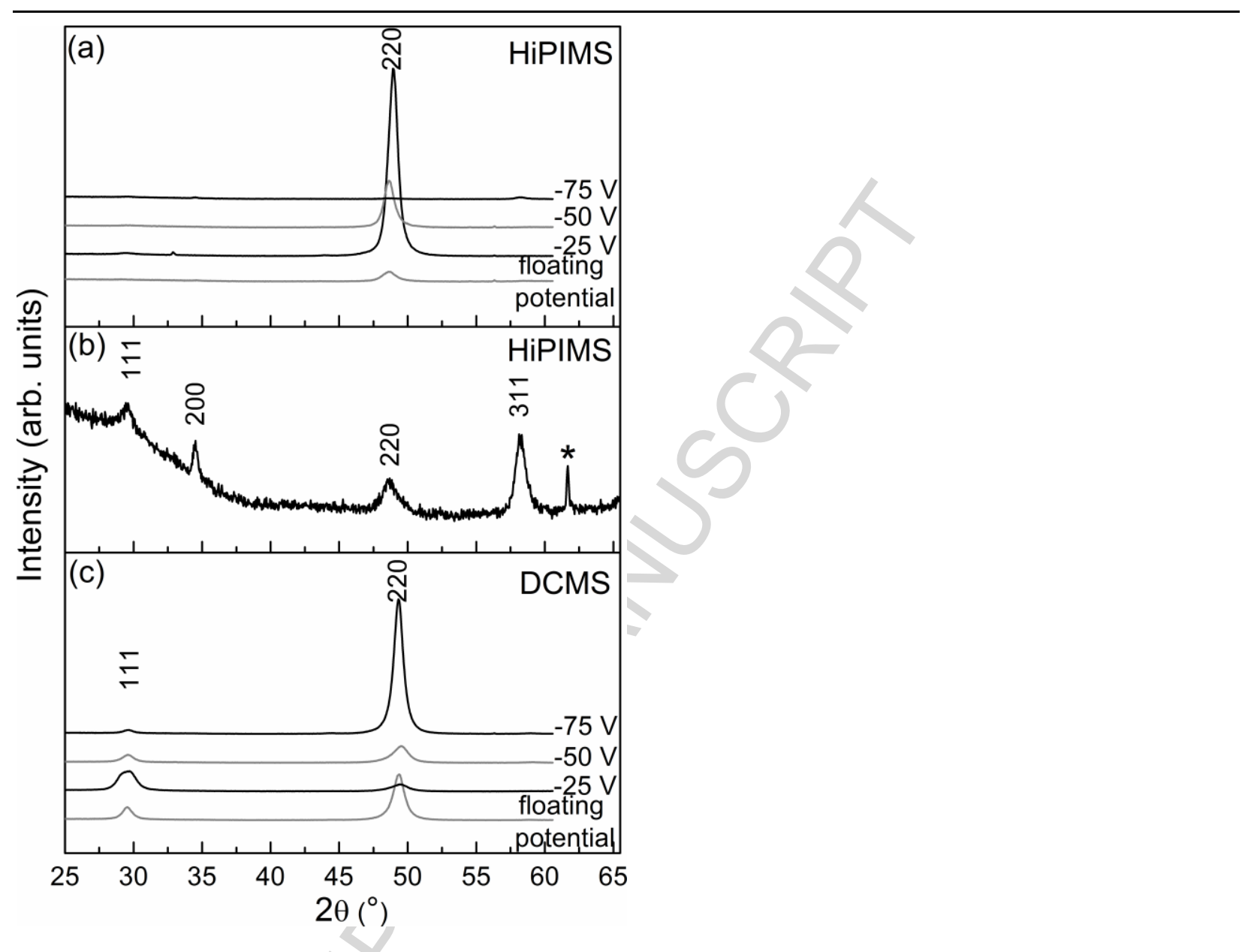

Figure 1 


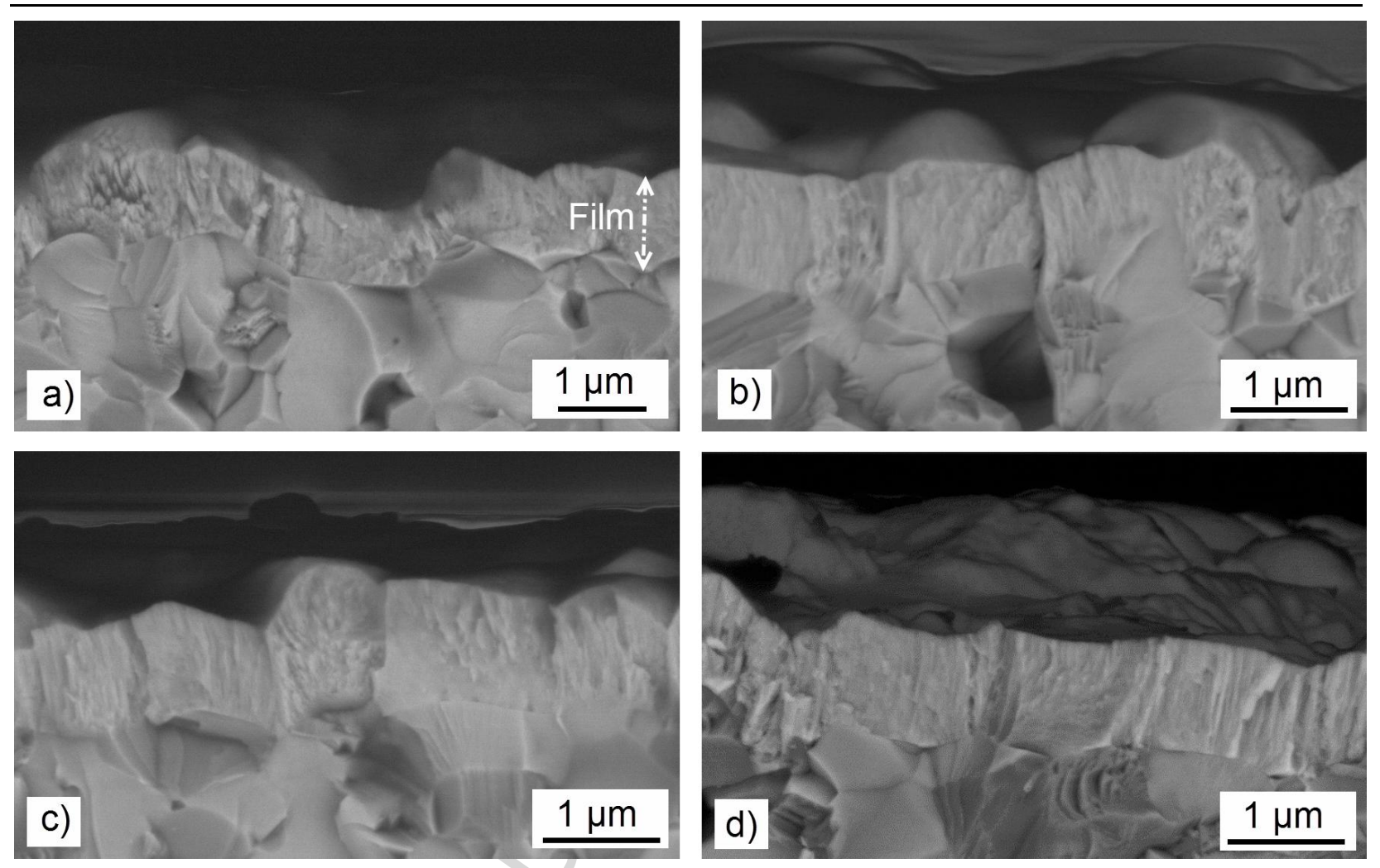

Figure 2 

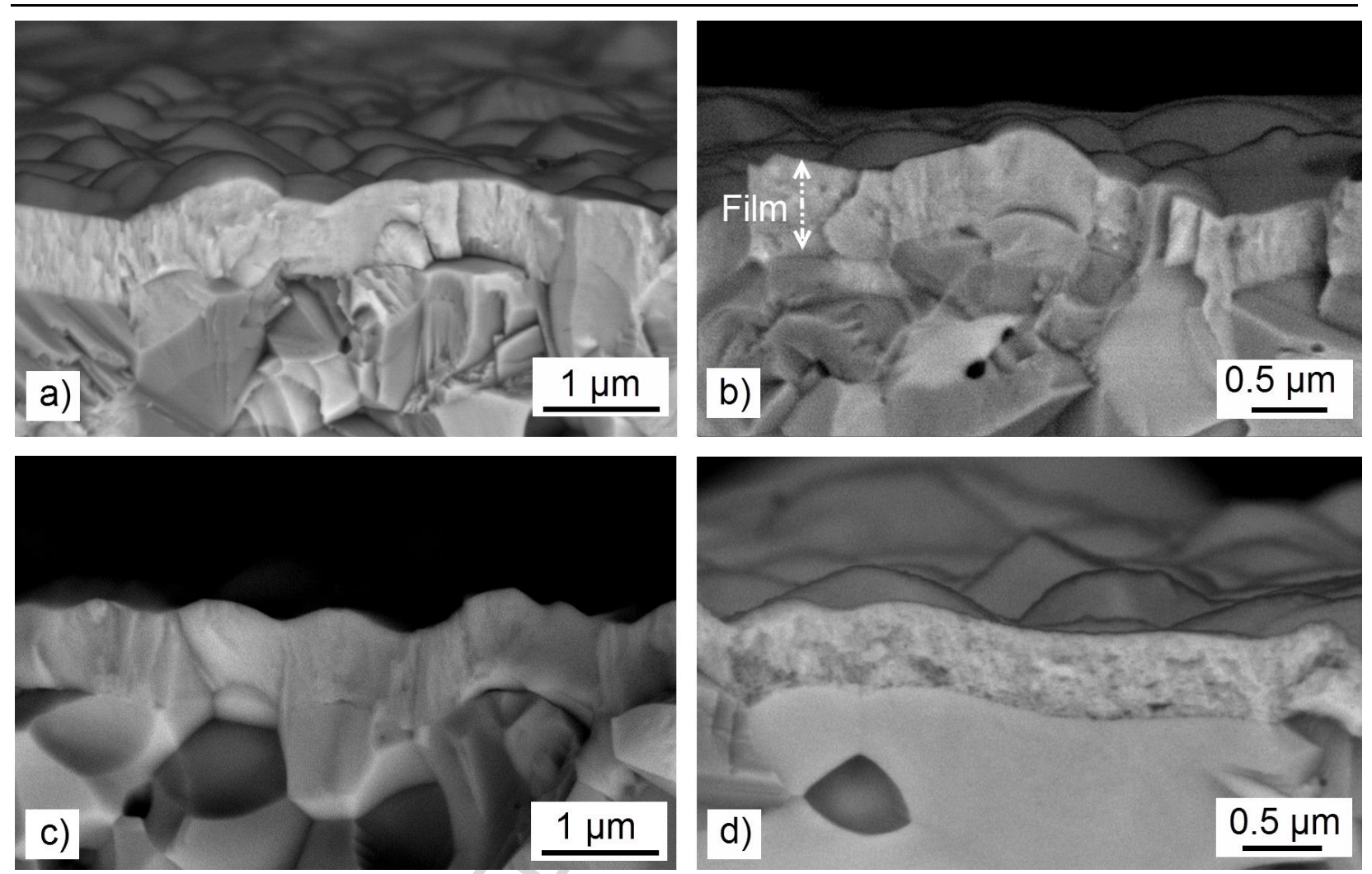

Figure 3 

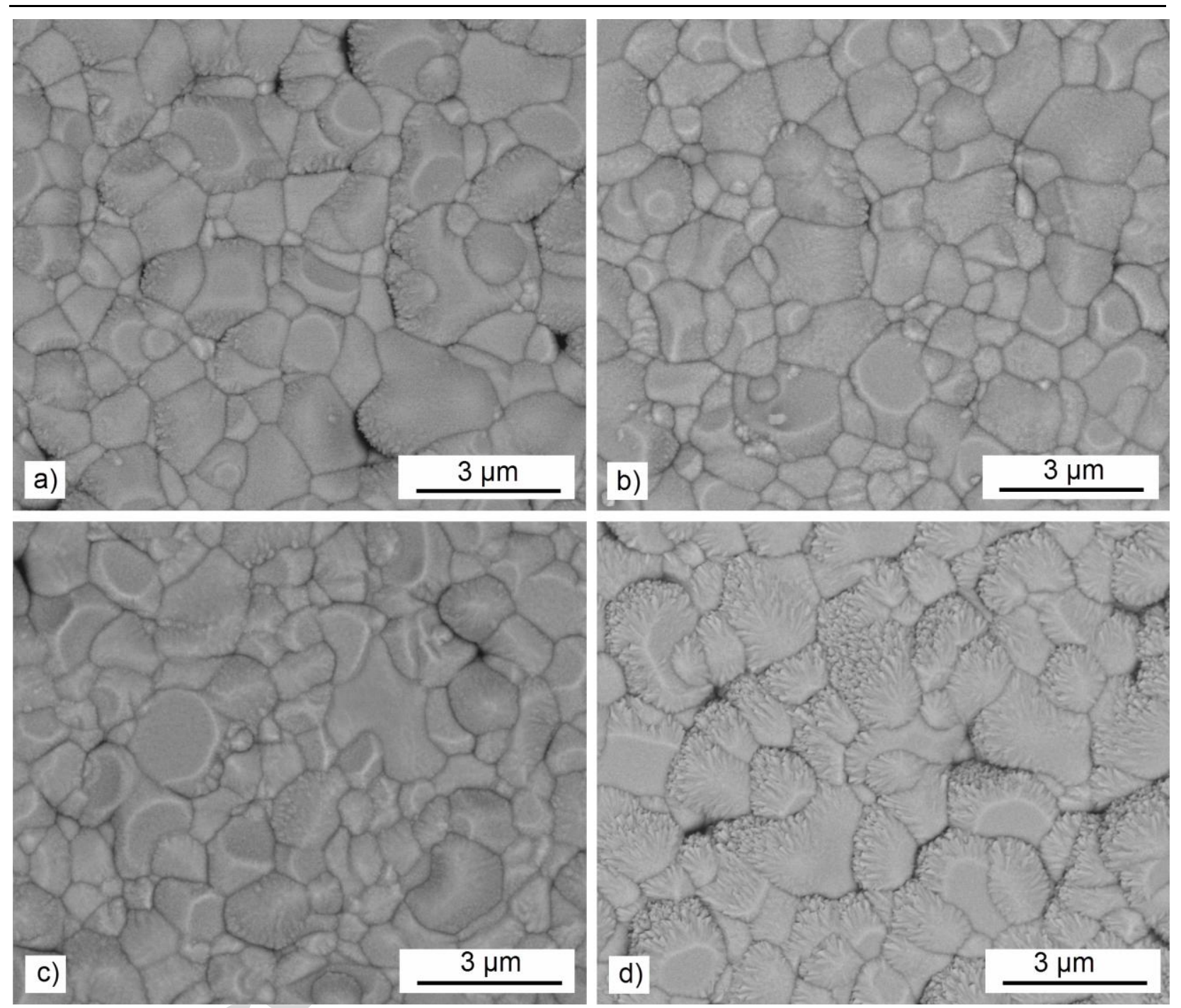

\section{Figure 4}




\section{ACCEPTED MANUSCRIPT}
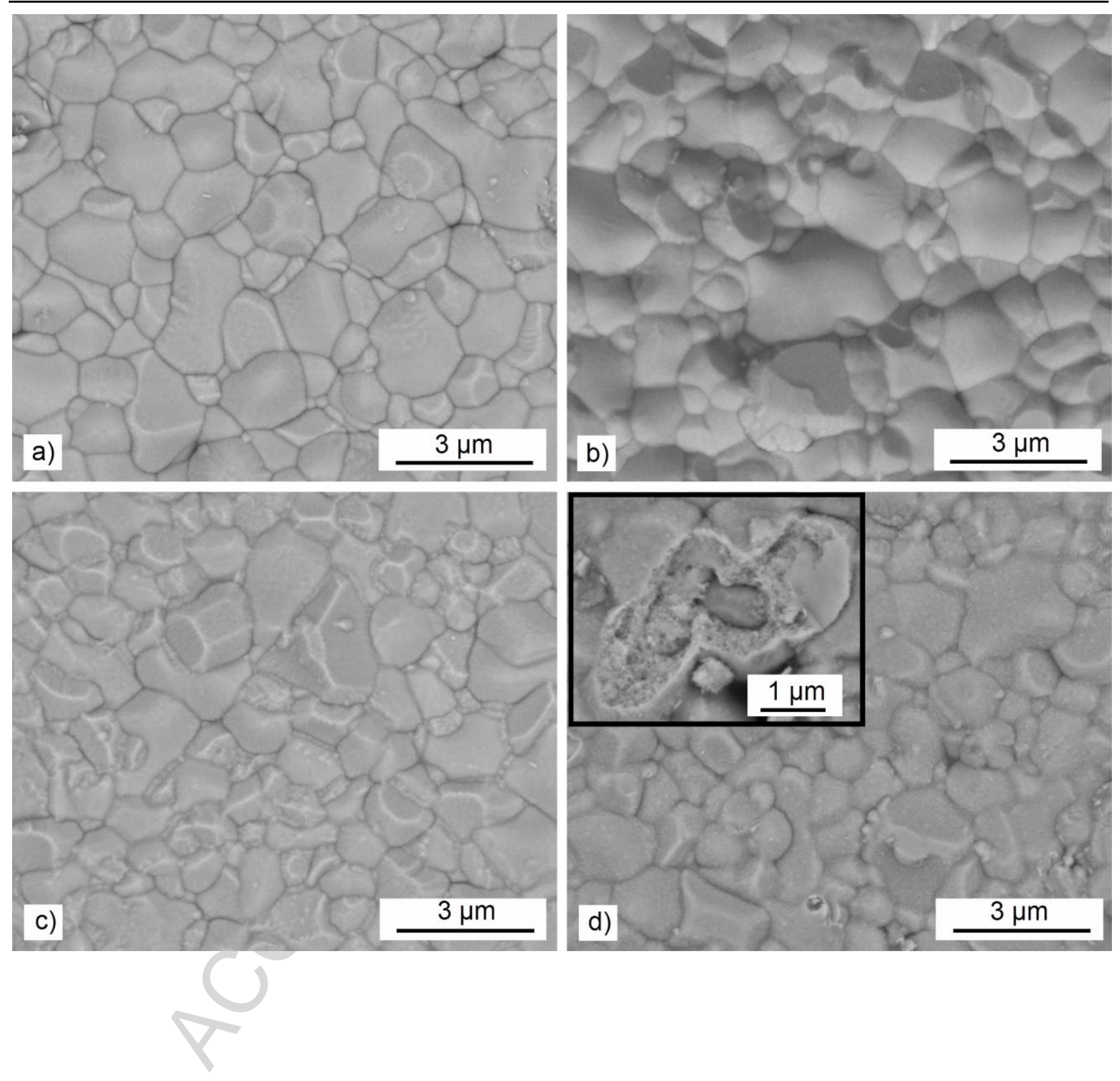

Figure 5 
Table I

Film composition measured by RBS and EDX. The theoretical composition for a fully stoichiometric film deposited with a $82: 18 \mathrm{wt} . \% \mathrm{Zr} / \mathrm{Y}$ target is also shown.

\begin{tabular}{c|c|c|c|c|c|c|c} 
& \multicolumn{3}{c|}{ HiPIMS } & \multicolumn{2}{c|}{ Pulsed DCMS } & Theoretical composition \\
\hline & $\begin{array}{c}\text { Floating } \\
\text { potential }\end{array}$ & $\begin{array}{c}-25 \mathrm{~V} \\
\text { bias }\end{array}$ & $\begin{array}{c}-50 \mathrm{~V} \\
\text { bias }\end{array}$ & $\begin{array}{c}-75 \mathrm{~V} \\
\text { bias }\end{array}$ & $\begin{array}{c}\text { Floating } \\
\text { potential }\end{array}$ & $-50 \mathrm{~V}$ bias & 65.6 \\
\hline $\begin{array}{c}\text { O } \\
\text { (at.\%) }\end{array}$ & 64.4 & 66.9 & 65.1 & 64.9 & 65.2 & 64.8 & 0.5 \\
\hline $\begin{array}{c}\text { Hf } \\
\text { (at.\%) }\end{array}$ & 0.4 & 0.7 & 0.6 & 0.6 & 0.5 & 0.5 & 27.6 \\
\hline $\begin{array}{c}\text { Zr } \\
\text { (at.\%) }\end{array}$ & 28.6 & 26.5 & 28.0 & 28.1 & 27.9 & 28.0 & 6.3 \\
\hline Y & 6.6 & 6.0 & 6.2 & 6.4 & 6.5 & 6.8 & \\
$($ at.\% $)$ & & & & & & &
\end{tabular}




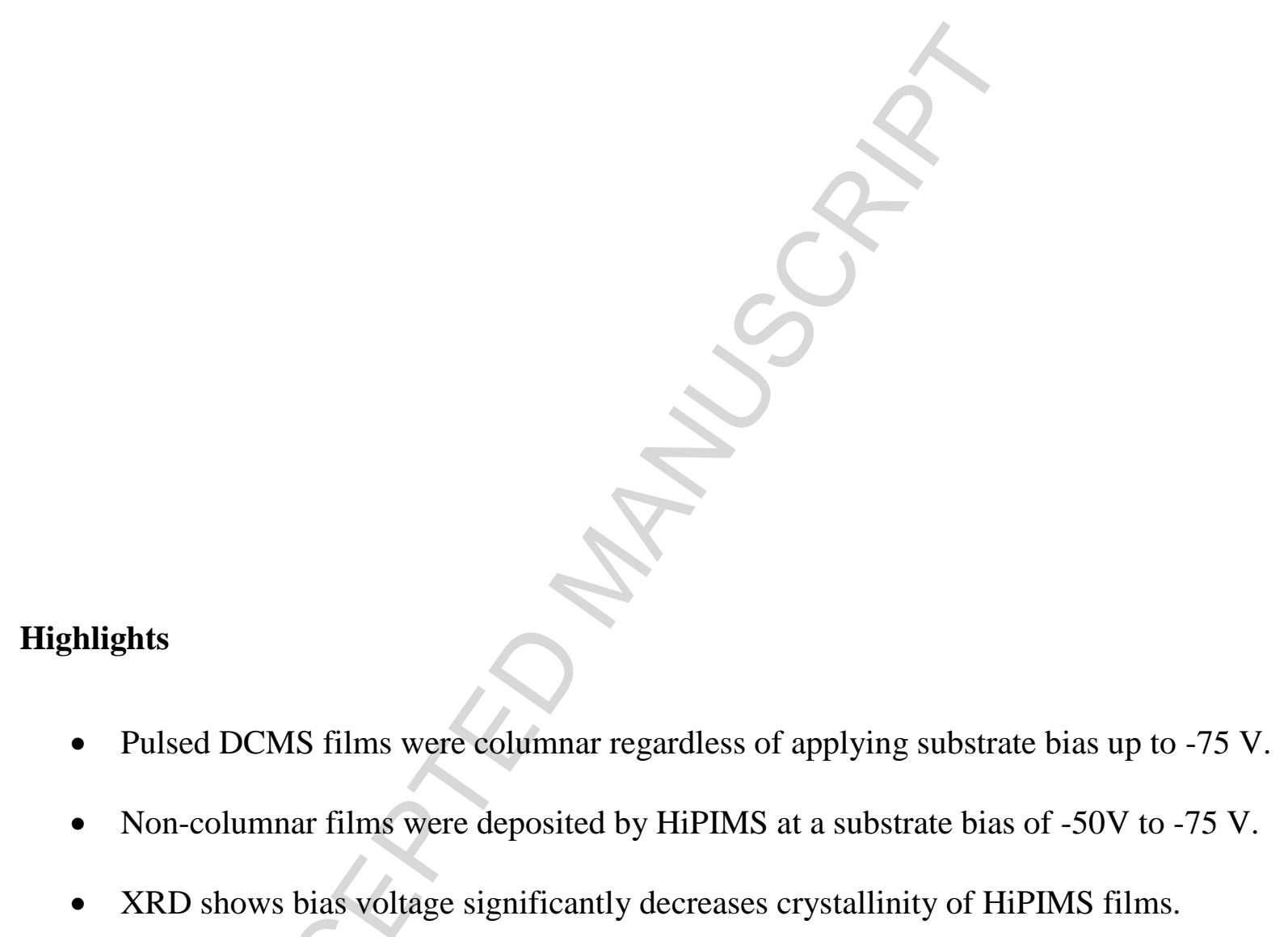

